
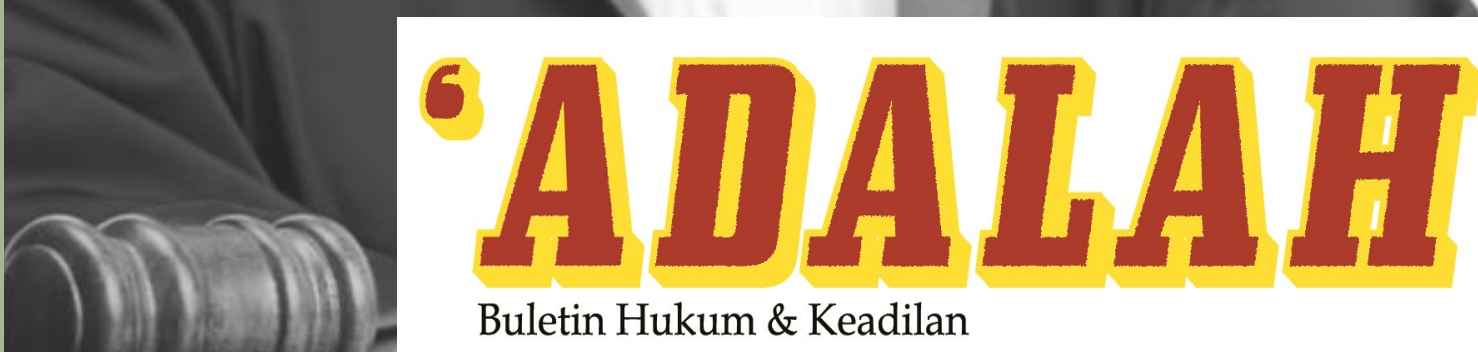

Buletin Hukum \& Keadilan

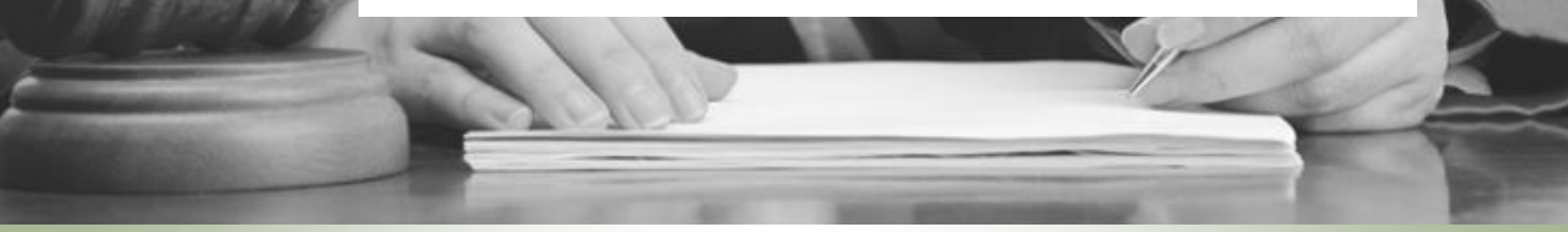

\title{
Bersekongkol Membubarkan Komisi Pemberantasan Korupsi
}

Cicik Nawang Putri, Helmi Alwi, Budi Suharto

Fakultas Hukum Universitas 17 Agustus 1945 Surabaya

do:

10.15408/adalah.v4i3.16271

Abstract:

The purpose of this study is to determine the legal implications of the loss of the authority to investigate and prosecute and the responsibility of the leadership of the Corruption Eradication Commission (KPK). In this study using empirical research methods. This researcher offers something new, namely the weakening of the KPK institutions which has an impact on the less than optimal performance of corruption eradication and even results in the cessation of efforts to investigate, investigate and prosecute various corruption cases, which could have implications for the dissolution of the KPK institutions. The results of this study stated that the loss of the authority to investigate and prosecute and the responsibilities of the KPK leadership resulted in a decline in KPK performance, because it could not work optimally.

Keywords: Fundamental, Legal Implications, Authority, Investigation, Prosecution

\section{Abstrak:}

Tujuan dari penelitian ini adalah untuk mengetahui implikasi hukum dari hilangnya kewenangan menyidik dan menuntut serta tanggung jawab dari pimpinan KPK. Dalam penelitian ini menggunakan metode penelitian empi ris. Peneliti ini menawarkan suatu hal yang baru, yaitu dilemahkannya lembaga KPK yang berimbas pada kurang optimalnya kinerja pemberantasan korupsi dan bahkan mengakibatkan terhentinya upaya penyelidikan, penyidikan dan penuntutan berbagai kasus korupsi, yang dapat berimplikasi pada dibubarkannya lembaga KPK. Hasil penelitian ini menyatakan bahwa dengan hilangnya kewenangan menyidik dan menuntut serta tanggung jawab pimpinan KPK mengakibatkan menurunnya kinerja KPK, karena tidak dapat bekerja dengan optimal.

Kata Kunci: Fundamental, Implikasi Hukum, Kewenangan, Penyidikan, Penuntutan 


\section{Prolog}

Komisi Pemberantasan Korupsi (KPK) selama ini memegang kendali upaya pemberantasan korupsi dengan berbagai kewenangan yang dimilikinya. Hal ini disebabkan karena Kepolisian dan Kejaksaan dianggap tidak bekerja efektif dalam memberantas korupsi. Operasi tangkap tangan yang dilakukan KPK dinilai maksimal oleh kalangan pakar pidana dan masyarakat. Upaya pemberantasan korupsi selalu diawali dengan operasi tangkap tangan oleh KPK dengan hasil cukup maksimal menjerat para pelaku korupsi dari berbagai cabang kekuasaan ke dalam jeruji besi.

Saat ini pemerintah telah mengeluarkan Undang-Undang Nomor 19 Tahun 2019. Dalam Undang-Undang Nomor 30 Tahun 2002 (UU KPK yang lama) pada Pasal 21 ayat (4) menyatakan bahwa kewenangan dari para pimpinan KPK dalam hal menyidik dan menuntut telah dihapus sebagaimana dalam UU KPK yang baru, begitu juga dengan ayat (6) UU KPK lama dimana para pimpinan KPK bukan lagi sebagai penanggung jawab tertinggi dalam tubuh lembaga tersebut. Tanpa adanya persetujuan dari para pimpinan KPK tentu saja proses penyelidikan dan penyidikan pengungkapan suatu kasus korupsi tidak dapat dilaksanakan, sehingga dapat menunda bahkan menghentikan pengungkapan kasus korupsi.

Korupsi tentu saja dilakukan oleh pejabat yang memiliki kekuasaan. Oleh karena itu dengan tidak dimilikinya lagi kewenangan para pimpinan KPK dalam menyidik dan menuntut serta penanggung jawab tertinggi bukan lagi para pimpinan KPK, maka dapat dipastikan kendali pemberantasan korupsi akan hilang dan komisioner KPK hanya akan menjalankan tugas administrasi (kompas.tv, 2020).

Kewenangan dan tanggung jawab para pimpinan KPK sesuai pasal 21 ayat (4) dan ayat (6) Undang-Undang Nomor 30 Tahun 2002 harus tetap ada, karena hal ini merupakan kewenangan yang sangat fundamental dalam upaya pemberantasan korupsi. Selain, dengan tidak adanya kewenangan dalam menyidik dan menuntut, maka 
tidak akan ada pengungkapan suatu kasus korupsi yang selalu dimulai dengan suatu proses penyelidikan dan penyidikan dalam hal menemukan bukti dan tersangka, serta menetapkan hukuman yang maksimal untuk menjerat para pelaku korupsi ke dalam jeruji besi (Liputan6.com).

Kewenangan yang sangat fundamental ini dan tanggung jawab dari para pimpinan KPK juga diperlukan agar para pimpinan KPK dapat memerintahkan secara langsung para penyidik dan penuntut umum dari Kepolisian dan Kejaksaan. Sehingga upaya pemberantasan korupsi dapat berjalan efektif. Akan tetapi, jika hal ini tidak dapat dilakukan, maka KPK tentu saja dapat dibubarkan karena kendali pemberantasan korupsi tidak lagi berada di

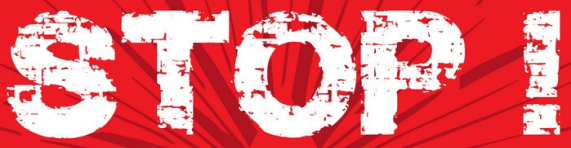
CORRUPTION

International Anti Corruption Day

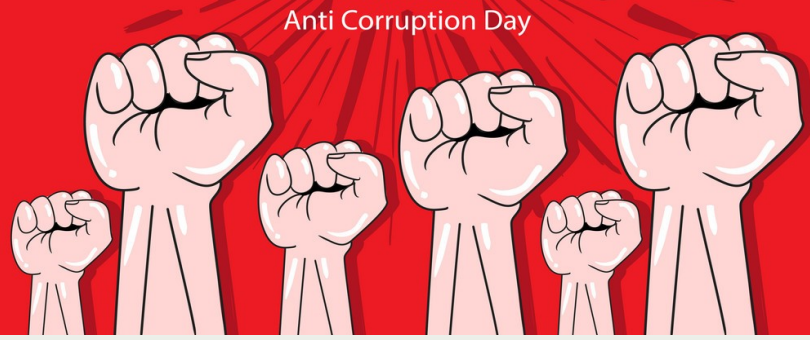
tangan KPK, sehingga lembaga KPK tidak diperlukan lagi.

Penelitian ini juga melengkapi penelitian-penelitian sebelumnya tentang kinerja lembaga KPK, selain juga menawarkan suatu hal yang baru tentang apa yang terjadi dengan dihilangkannya kewenangan dan tanggung jawab pada pimpinan KPK, yaitu dilemahkannya lembaga KPK yang berimbas pada kurang optimalnya kinerja pemberantasan korupsi dan bahkan mengakibatkan terhentinya upaya penyelidikan, penyidikan dan penuntutan berbagai kasus korupsi besar, karena hilangnya kewenangan yang sangat fundamental ini, yang tentu saja berimplikasi pada dibubarkannya lembaga KPK.

Berdasarkan pemaparan tersebut diatas, maka dapat dirumuskan masalah penelitian, yaitu dapatkah KPK dibubarkan dengan menghilangkan kewenangan menyidik dan menuntut serta 
tanggung jawab tertinggi pimpinan KPK dalam Pasal 21 UndangUndang Nomor 19 Tahun 2019?

\section{Kewenangan KPK}

Dalam ilmu politik, ilmu pemerintahan, dan ilmu hukum sering kali ditemukan istilah kekuasaan, kewenangan, dan wewenang. Kekuasaan sering disamakan dengan kewenangan, dan kekuasaan sering dipertukarkan dengan kewenangan, dan sebaliknya. Terkadang juga kewenangan sering disamakan dengan wewenang. Kekuasaan menunjukkan bahwa "ada satu pihak yang memerintah dan di pihak lain diperintah" (Budiardjo, 1998).

Ateng Syafruddin berpendapat ada perbedaan antara pengertian kewenangan dan wewenang (Syafruddin, 2000: 22). Kita harus membedakan antara kewenangan (authority, gezag) dengan wewenang (competence, bevoegheid). Kewenangan adalah apa yang disebut kekuasaan formal, kekuasaan yang berasal dari kekuasaan yang diberikan oleh undang-undang, sedangkan wewenang hanya mengenai suatu "onderdeel" (bagian) tertentu saja dari kewenangan. Di dalam kewenangan terdapat wewenang-wewenang (rechtsbe voegdheden). Wewenang merupakan lingkup tindakan hukum publik, lingkup wewenang pemerintahan, tidak hanya meliputi wewenang membuat keputusan pemerintah (bestuur), tetapi meliputi wewenang dalam rangka pelaksanaan tugas, dan memberikan wewenang serta distribusi wewenang utamanya ditetapkan dalam peraturan perundang-undangan. Secara yuridis, pengertian wewenang adalah kemampuan yang diberikan oleh peraturan perundang-undangan untuk menimbulkan akibat-akibat hukum (Indroharto, 1994: 65).

Dari berbagai pengertian kewenangan sebagaimana tersebut di atas, dapat disimpulkan bahwa kewenangan (authority) memiliki pengertian yang berbeda dengan wewenang (competence). Kewenangan merupakan kekuasaan formal yang berasal dari undang-undang, sedangkan wewenang adalah suatu spesifikasi dari 
kewenangan, artinya barang siapa (subyek hukum) yang diberikan kewenangan oleh undang-undang, maka ia berwenang untuk melakukan sesuatu yang tersebut dalam kewenangan itu.

Kewenangan sebagai konsep hukum publik sekurangkurangnya terdiri dari tiga komponen, yaitu (Winarno, 2008: 66): 1). Komponen pengaruh adalah bahwa penggunaan wewenang dimaksudkan untuk mengendalikan perilaku subjek hukum; 2). Komponen dasar bahwa wewenang itu selalu dapat ditunjukkan dasar hukumnya; 3). Komponen konformitas mengandung makna adanya standar wewenang yaitu standar umum (semua jenis wewenang) dan standar khusus (untuk wewenang tertentu).

Penyidikan dan Penuntutan oleh KPK

Dalam tindakan penyelidikan penekanannya terletak pada tindakan "mencari dan menemukan suatu peristiwa" dianggap atau sebagai tindak pidana, maka

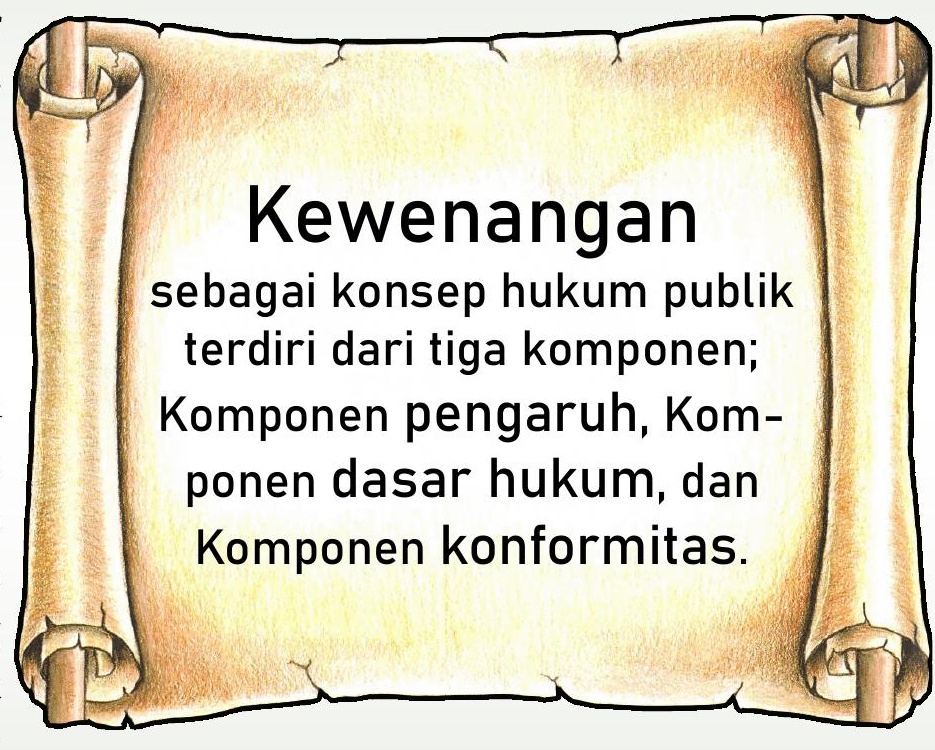
pada tindakan penyidikan titik beratnya diletakkan pada tindakan mencari serta mengumpulkan bukti supaya tindak pidana yang ditemukan dapat menjadi terang serta agar dapat menemukan pelakunya. Sebagaimana disebutkan dalam Pasal 1 ayat (2) UndangUndang Kitab Hukum Acara Pidana (KUHAP), bahwa: Penyidikan adalah serangkaian tindakan penyidik dalam hal dan menurut cara yang diatur dalam undang-undang ini untuk mencari serta mengumpulkan bukti yang dengan bukti itu membuat terang tentang tindak pidana yang terjadi dan guna menemukan tersangkanya. Dengan kata lain tindakan penyidikan merupakan cara untuk mengumpulkan bukti-bukti awal untuk mencari 
tersangka yang diduga melakukan tindak pidana dan saksi-saksi yang mengetahui tentang tindak pidana tersebut (Mukhlis, 2012: 57).

Mengenai kewenangan penyidik diatur dalam Pasal 7 ayat (1), (2) dan (3), yaitu:

(1) "Penyidik sebagaimana dimaksud dalam Pasal 6 ayat (1) huruf a karena kewajibannya mempunyai wewenang; a). Menerima laporan atau pengaduan dari seorang tentang adanya tindak pidana; b). Melakukan tindakan pertama pada saat di tempat kejadian; c). Menyuruh berhenti seorang tersangka dan memeriksa tanda pengenal diri tersangka; d). Melakukan penangkapan, penahanan, penggeledahan dan penyitaan; e). Melakukan pemeriksaan dan penyitaan surat; f). Mengambil sidik jari dan memotret seorang; g). Memanggil orang untuk didengar dan diperiksa sebagai tersangka atau saksi; h). Mendatangkan orang ahli yang diperlukan dalam hubungannya dengan pemeriksaan perkara; i). Mengadakan penghentian penyidikan; j). Mengadakan tindakan lain menurut hukum yang bertanggung jawab.

(2) Penyidik sebagaimana dimaksud dalam Pasal 6 ayat (1) huruf $b$ mempunyai wewenang sesuai dengan undangundang yang menjadi dasar hukumnya masing-masing dan dalam pelaksanaan tugasnya berada dibawah koordinasi dan pengawasan penyidik tersebut dalam Pasal 6 ayat (1) huruf a.

(3) Dalam melakukan tugasnya sebagaimana dimaksud dalam ayat (1) dan ayat (2), penyidik wajib menjunjung tinggi hukum yang berlaku.

\section{Penuntutan}

Ketentuan mengenai penuntutan diatur dalam Pasal 1 ayat (7) KUHAP, sebagaimana disebutkan bahwa: penuntutan adalah 
tindakan penuntut umum untuk melimpahkan perkara pidana ke pengadilan negeri yang berwenang dalam hal dan menurut cara yang diatur dalam undang-undang ini dengan permintaan supaya diperiksa dan diputus oleh hakim di sidang pengadilan.

Mengenai kewenangan penuntut umum diatur dalam Pasal 14, penuntut umum mempunyai wewenang, sebagai berikut :

a. Menerima dan memeriksa berkas perkara penyidikan dari penyidik atau penyidik pembantu;

b. Mengadakan prapenuntutan apabila ada kekurangan pada penyidikan dengan memperhatikan ketentuan Pasal 110 ayat

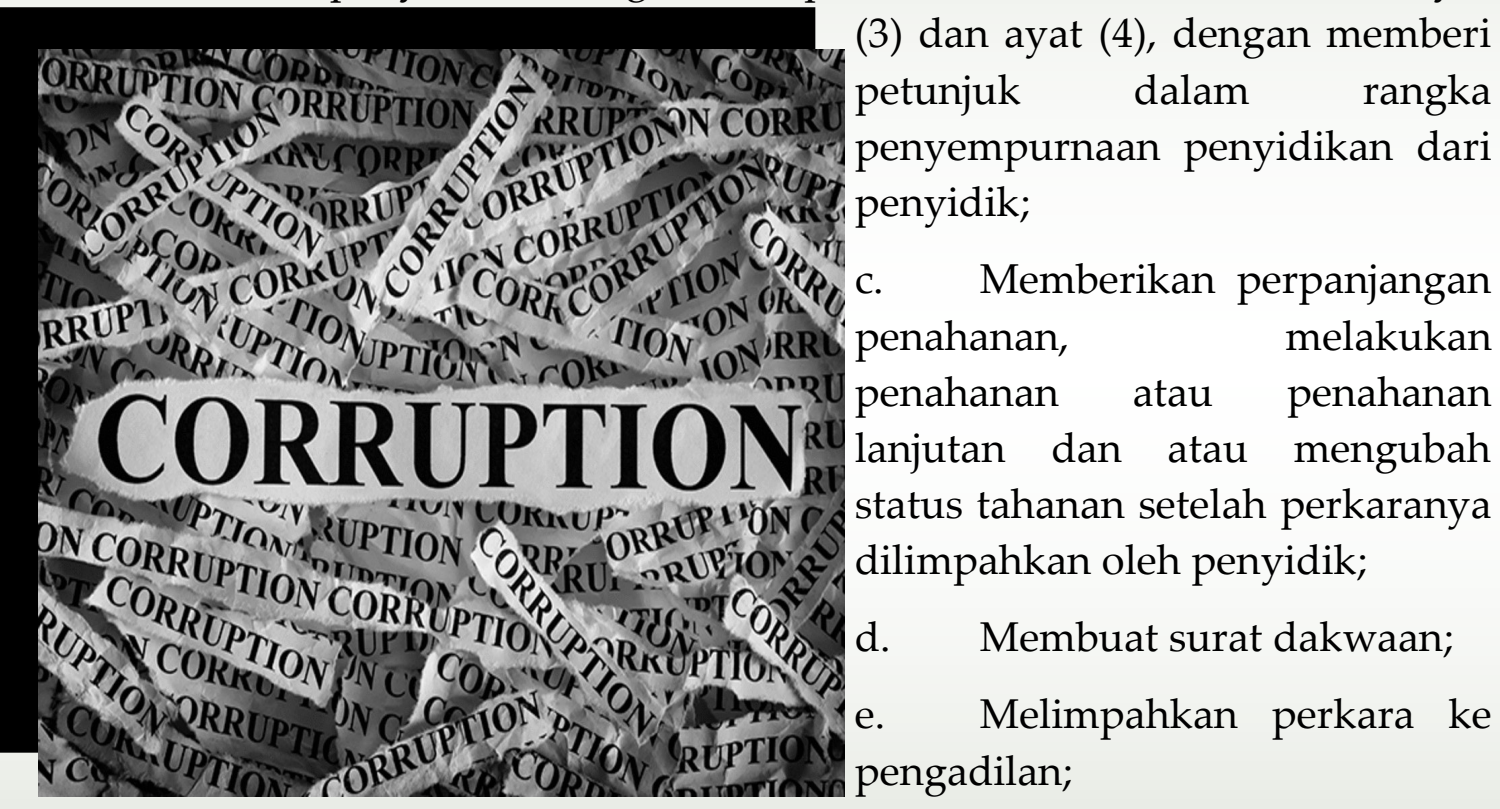

f. Menyampaikan pemberitahuan kepada terdakwa tentang ketentuan hari dan waktu perkara disidangkan yang disertai surat panggilan, baik kepada terdakwa maupun kepada saksi, untuk datang pada sidang yang telah ditentukan;

g. Melakukan penuntutan;

h. Menutup perkara demi kepentingan hukum;

i. Mengadakan tindakan lain dalam lingkup tugas dan tanggung 
jawab sebagai penuntut umum menurut ketentuan undangundang ini;

j. Melaksanakan penetapan hakim.

\section{Implikasi Hukum}

Dalam Kamus Besar Bahasa Indonesia (KBBI), makna kata implikasi adalah keterlibatan atau keadaan terlibat. Sehingga setiap kata imbuhan berasal dari implikasi seperti kata berimplikasi atau mengimplikasikan yakni berarti mempunyai hubungan keterlibatkan atau melibatkan dengan suatu hal (KBBI online, 2020).

Menurut M. Irfan Islamy, implikasi adalah segala sesuatu yang telah dihasilkan dengan adanya proses perumusan kebijakan (Islamy, 2003: 114-115). Dengan kata lain implikasi adalah akibatakibat dan konsekuensi-konsekuensi yang ditimbulkan dengan dilaksanakannya kebijakan atau kegiatan tertentu. Sedang menurut Winarno, setidaknya ada lima dimensi yang harus dibahas dalam memperhitungkan implikasi dari sebuah kebijakan (Winarno, 2002: 171-174). Dimensi-dimensi tersebut meliputi:

1) Implikasi kebijakan pada masalah-masalah publik dan implikasi kebijakan pada orang-orang yang terlibat.

2) Kebijakan mungkin mempunyai implikasi pada keadaankeadaan atau kelompok-kelompok diluar sasaran atau tujuan kebijakan.

3) Kebijakan mungkin akan mempunyai implikasi pada keadaan -keadaan sekarang dan yang akan datang.

4) Evaluasi juga menyangkut unsur yang lain yakni biaya langsung yang dikeluarkan untuk membiayai programprogram kebijakan publik.

5) Biaya-biaya tidak langsung yang ditanggung oleh masyarakat atau beberapa anggota masyarakat akibat adanya kebijakan publik. 
Menurut Silalahi, implikasi adalah akibat yang ditimbulkan dari adanya penerapan suatu program atau kebijakan, yang dapat bersifat baik atau tidak terhadap pihak-pihak yang menjadi sasaran pelaksanaan program atau kebijaksanaan tersebut (Silalahi, 2005: 43).

Berdasarkan beberapa pendapat di atas, maka yang dimaksud dengan implikasi dalam penelitian ini adalah suatu akibat yang terjadi atau ditimbulkan dari suatu peristiwa, pelaksanaan kebijakan atau program tertentu bagi sasaran pelaksanaan kebijakan yang bersifat baik atau tidak baik, pada keadaan-keadaan sekarang maupun yang akan datang.

Dari hasil wawancara yang didapat bahwa keberadaan lembaga KPK saat ini kurang efektif, KPK harus dapat memaksimalkan peran serta penyelidik dan penyidik untuk lebih banyak mengungkapkan kasus korupsi. Untuk itu pimpinan KPK harus dapat mengendalikan penyelidik dan penyidiknya melalui wewenang yang dimilikinya, akan tetapi dengan hilangnya kewenangan penyidikan dan penuntutan pimpinan KPK dalam Pasal 21 Undang-Undang Nomor 19 Tahun 2019 ini tentu saja dapat mengganggu pengendalian pimpinan KPK terhadap penyidik dan penuntutnya seperti halnya disebuah instansi atau di kantor apapun yang dilakukan anggota atau bawahan harus tetap seizin pimpinannya.

Jika kewenangan pimpinan KPK dalam penyidikan dan penuntutan dihilangkan, maka tentu saja, penyidikan dan penuntutan kasus Korupsi dapat terhenti atau berjalan ditempat, sehingga untuk apa KPK ada jika tidak dapat menuntaskan penyidikan dan penuntutan kasus korupsi, maka KPK tentu saja dapat dibubarkan. Dengan hilangnya kewenangan pimpinan KPK diikuti dengan lepasnya tanggung jawab dari pimpinan KPK, dimana pimpinan KPK tidak lagi sebagai penanggung jawab tertinggi pada lembaga yang dipimpinannya sendiri. Hal ini tentu saja tidak baik karena seharusnya pimpinan pada suatu lembaga mempunyai tanggung jawab penuh pada lembaga yang 
dipimpinnya. Hubungan kewenangan pimpinan sebagai penyidik dan penuntut dengan pimpinan KPK sebagai penanggung jawab tertinggi adalah suatu hubungan yang saling terkait, sehingga jika kedua hal ini dihilangkan tentu saja dengan demikian pimpinan pada suatu lembaga penegak hukum tersebut telah dibatasi kewenangan atau otoritasnya, maka lembaga KPK akan menjadi suatu lembaga yang lemah dalam mencapai tujuan pemberantasan korupsi itu sendiri.

\section{Epilog}

Dari hasil pemaparan tersebut diatas, dapat ditarik suatu kesimpulan, yaitu hilangnya kewenangan menyidik dan menuntut serta tanggung jawab pimpinan KPK mengakibatkan menurunnya kinerja KPK karena tidak dapat bekerja dengan optimal. Dengan dihilangkannya kewenangan dan tanggung jawab pimpinan KPK akan mengakibatkan terjadinya penyalahgunaan wewenang oleh pimpinan KPK. Dalam UU Nomor 19 Tahun 2019 justru ada upaya untuk melemahkan kendali pemberantasan korupsi bahkan dapat menyebabkan dibubarkannya KPK dengan hilangnya kontrol pimpinan KPK secara langsung terhadap penyidikan dan penuntutan.

Saran yang dapat diberikan, yaitu agar lembaga KPK dapat bekerja optimal untuk mengungkap dan memberantas berbagai kasus korupsi seharusnya kewenangan menyidik dan menuntut serta tanggung jawab dari pimpinan KPK yang sebelumnya dimiliki oleh pimpinan KPK dikembalikan agar pimpinan KPK dapat mengendalikan secara langsung penyidik dan penuntut umum sehingga kendali pemberantasan korupsi berada dibawah kendali KPK.

\section{Referensi:}

Syafruddin, Ateng. 2000. Menuju Penyelenggaraan Pemerintahan Negara yang Bersih dan Bertanggung Jawab, Jurnal Pro Justisia 
Edisi IV, Bandung: Universitas Parahyangan.

Detiknews "UU KPK Baru Berlaku, Ini Pasal-pasal yang Mulai Aktif", diakses pada 1 Mei 2020.

Indroharto, 1994. Asas-Asas Umum Pemerintahan yang Baik, dalam Paulus Efendie Lotulung, Himpunan Makalah Asas-Asas Umum Pemerintahan yang Baik, Bandung: Citra Aditya Bakti.

KBBI Online, Arti Kata Implikasi, diakses dari http://kbbi.web.id/ implikasi, pada 31 Mei 2020.

Liputan6.com "Pengamat : Bila Tak Bisa Lakukan Penyelidikan, KPK Bubarkan Saja", diakses pada 4 Mei 2020.

Budiardjo, Miriam. 1998. Dasar-Dasar Ilmu Politik, Jakarta: Gramedia Pustaka Utama.

Mukhlis. 2012. "Pergeseran Kedudukan dan Tugas Penyidik POLRI dengan Perkembangan Delik-delik di Luar KUHP" Artikel pada Jurnal Ilmu Hukum, Fakultas Hukum Universitas Riau, Vol. 3, No. 1 Agustus.

Winarno, Nur Basuki. 2008. Penyalahgunaan Wewenang dan Tindak Pidana Korupsi, Jogjakarta: Laksbang Mediatama.

Tribunnews "Pengawat: KPK Telah Dilumpuhkan, Sebaiknya Dibubarkan Saja", diakses pada 6 Mei 2020.

Youtube Kompastv "Revisi UU KPK Disahkan, Bagaimana Masa Depam Pemberantasan Korupsi", diakses pada 1 Mei 2020.

Maggalatung, A.S.; Aji, A.M.; Yunus, N.R. 2014. How The Law Works, Jakarta: Jurisprudence Institute.

'Adalah; Buletin Hukum dan Keadilan merupakan berkala ilmiah yang diterbitkan oleh Pusat Studi Konstitusi dan Legislasi Nasional (POSKO-LEGNAS), Fakultas Syariah dan Hukum UIN Syarif Hidayatullah Jakarta.

Penasehat: Prof. Dr. H. Abdul Ghani Abdullah, SH., Prof. Dr. H. A Salman Maggalatung, SH., MH. Tim Redaktur: Indra Rahmatullah, Mara Sutan Rambe, Muhammad Ishar Helmi, Erwin Hikmatiar, Fathuddin, Nurrohimyunus. Penyunting: Latipah Nasution, Siti Nurhalimah, Siti Romlah. Setting \& Layout: Imas Novita Juaningsih. 